\title{
Pleiotropic effects of the $\mathrm{CB}_{2}$ cannabinoid receptor activation on human monocyte migration: implications for atherosclerosis and inflammatory diseases
}

\author{
Pál Pacher ${ }^{1}$ and Zoltán Ungvári ${ }^{2}$ \\ 1 Section on Oxidative Stress Tissue Injury, Laboratory of Physiological Studies, National Institutes of Health, \\ NIAAA, 5625 Fishers Lane MSC 9413, Room 2N17, Bethesda MD 20892-9413, USA
}

2 Department of Physiology, New York Medical College, Valhalla, NY 10595, USA

Endocannabinoids are endogenous lipid mediators, generated by practically all cell types both in the central nervous system and in peripheral tissues, which exert wide range of biological effects (e.g. psychoactive, analgesic, cardiovascular, and anti-inflammatory, etc.) similar to those of cannabis via activation of two main $\mathrm{G}$ protein-coupled cannabinoid $(\mathrm{CB})$ receptors: the $\mathrm{CB}_{1}$ and the $\mathrm{CB}_{2}$ receptors $(7,9,13,17,20)$. Emerging recent evidence also supports the possible existence of additional yet unidentified $\mathrm{CB}$ receptors, and endocannabinoids may also exert multiple effects unrelated to $\mathrm{CB}$ receptors (5). The dysregulation of the endocannabinoid system (ES) has recently been implicated in many human diseases, and its pharmacological modulation holds tremendous promise in the treatment of pain, neurodegenerative, metabolic, cardiovascular, and inflammatory disorders, and cancer $(7,9,17,20)$.

The $\mathrm{CB}_{2}$ receptor was previously considered to be expressed predominantly in immune and hematopoietic cells (overviewed in (17)), but more recent studies have also found it in the brain (26), myocardium $(11,16)$ and endothelial cells of various origins (overviewed in (18)). Since $\mathrm{CB}_{2}$ receptor activation mediates various beneficial effects in preclinical disease models, the development of selective $\mathrm{CB}_{2}$ receptor agonists for therapeutic indications, which are devoid of psychoactive properties of $\mathrm{CB}_{1}$ agonists, has attracted considerable interest over the past couple of years $(9,17,20)$. Indeed, numerous recent studies have demonstrated antiinflammatory effects of $\mathrm{CB}_{2}$ receptor activation in a multitude of disparate diseases and pathological conditions, ranging from neurodegenerative disorders $(2,19)$, inflammatory pain (8), atherosclerosis $(24,25)$, myocardial $(6,11)$, cerebral $(28)$ and hepatic ischemia/reperfusion (I/R) injury $(3,18,23)$, to gastrointestinal inflammatory disorders (27), liver inflammation and fibrosis (12), to mention just a few.

The migration of inflammatory cells, mainly monocytes, into the arterial wall is a crucial event during atherogenesis. This process is orchestrated by chemokines, chemokine receptors as well as adhesion molecules. Steffens and colleagues using the apolipoprotein E knockout mice have previously provided experimental evidence on a possible role of $\mathrm{CB}_{2}$ receptors in atherosclerosis progression (25). Oral administration of low doses of delta-9tetrahydrocannabinol (THC), which exerts various effects on both $\mathrm{CB}_{1}$ and $\mathrm{CB}_{2}$ receptors,

Correspondence to: Zoltán Ungvári M.D., Ph.D., Department of Physiology, New York Medical College, Valhalla, NY 10595, USA. zoltan_ungvari@nymc.edu Or Pál Pacher M.D., Ph.D., F.A.H.A., Section on Oxidative Stress and Tissue Injury, Laboratory of Physiologic Studies, National Institutes of Health/NIAAA, 5625 Fishers Lane, MSC-9413, Bethesda, Maryland 20892-9413, USA. Phone: (301)443-4830; Fax: (301)480-0257; E-mail: pacher@mail.nih.gov.

Comment on: The CB2 cannabinoid receptor agonist JWH-015 modulates human monocyte migration through defined intracellular signaling pathways. by Fabrizio Montecucco, Fabienne Burger, Francoise Mach, and Sabine Steffens. Am J Physiol Heart Circ Physiol, Jan 2008; 10.1152/ajpheart.01328.2007. 
inhibited atherosclerotic plaque progression in mice. They have also demonstrated $\mathrm{CB}_{2}$ receptor expressing immune cells in mouse and human atherosclerotic plaques. Furthermore, lymphoid cells isolated from THC-treated mice had reduced proliferation capacity and decreased interferon-gamma production, and THC inhibited macrophage chemotaxis in vitro. Since all the above mentioned effects could largely be attenuated by a selective $\mathrm{CB}_{2}$, but not $\mathrm{CB}_{1}$ receptor antagonist, Authors hypothesized the crucial involvement of $\mathrm{CB}_{2}$ receptors on immune cells in atherosclerosis progression (25).

Several previous, mostly in vitro studies, have investigated the role of $\mathrm{CB}_{1} / \mathrm{CB}_{2}$ receptor activation on baseline or stimulated inflammatory and other cell migration, with both increases and decreases of cell migration being reported, depending on the trigger/condition,

endocannabinoid, synthetic agonist/antagonist, and cell type used (overviewed in $(9,10,14)$ ). Therefore, it is important to better understand the complex role of endocannabinoid signaling in inflammatory cell chemotaxis/migration and potential consequences of its pharmacological modulation by selective agonists and/or antagonists.

In their current study (15), Montecucco and colleagues have investigated the effect of $\mathrm{CB}_{2}$ cannabinoid receptor activation on the chemotactic response of human monocytes. They found that the $\mathrm{CB}_{2}$ receptor agonists JWH-015 and/or JWH-133 modulated the recruitment of human monocytes by various immediate and delayed effects. Prolonged (12 to $18 \mathrm{~h}$ ) preincubation with JWH-015 reduced monocyte migration to chemokines CCL2 and CCL3. This effect was likely due to reduced expression of the cognate chemokine receptors CCR2 and CCR1 and reduced IFN- $\gamma$ induced ICAM- 1 expression. These interesting findings should provide a basis for further research into the role of $\mathrm{CB}_{2}$ receptors in cardiovascular inflammatory diseases using genetically modified mice. Montecucco et al. convincingly showed that short term incubation with JWH-015 itself was chemoattractant for monocytes. Migration experiments using increasing JWH-015 gradients suggested that the cannabinoid-induced migration was rather directed chemotaxis than random movement. Moreover, JWH-015 cross-desensitized human monocytes for migration to CCL2 and CCL3. Indeed, it has been reported that certain chemoattractants desensitize the cells towards a further stimulation with other chemoattractants (1). This may have physiological relevance, as systemic administration of JWH-015 may desensitize the cells towards migration to inflammatory sites. Authors have also shown that the above mentioned effects of JWH- 015 could be mimicked by another selective $\mathrm{CB}_{2}$ agonist JWH-133, and largely attenuated by $\mathrm{CB}_{2}$ selective antagonist SR144528 supporting the involvement of $\mathrm{CB}_{2}$ receptors. Finally, the authors provided evidence that both short and long term effects were dependent on PI3K/Akt and ERK 1/2 signaling. Further studies are evidently needed to elucidate the role of the aforementioned pathways in animal models of inflammatory diseases.

In conclusion, these new findings, coupled with recent evidence demonstrating that $\mathrm{CB}_{2}$ receptor activation also attenuates TNF- $\alpha$-induced endothelial cell activation, transendothelial migration of monocytes and monocyte/neutrophil-endothelial adhesion $(3,4,21,23)$, and decreases TNF- $\alpha$-induced proliferation and migration of human coronary vascular smooth muscle cells by (22) by modulating distinct signaling pathways, provide important new mechanistic insights on the possible pleiotropic effects of $\mathrm{CB}_{2}$ activation in atherosclerosis and other inflammatory disorders.

\section{Acknowledgements}

This publication was supported by grants from the National Institute of Health (HL-077256; HL-43023 to Z.U.) and the Intramural Research program of NIH/NIAAA (to P.P.) 


\section{References}

1. Ali H, Richardson RM, Haribabu B, Snyderman R. Chemoattractant receptor cross-desensitization. J Biol Chem 1999;274:6027-6030. [PubMed: 10037679]

2. Arevalo-Martin A, Garcia-Ovejero D, Gomez O, Rubio-Araiz A, Navarro-Galve B, Guaza C, MolinaHolgado E, Molina-Holgado F. CB(2) cannabinoid receptors as an emerging target for demyelinating diseases: from neuroimmune interactions to cell replacement strategies. B J Pharmacol. 2008in press

3. Batkai S, Osei-Hyiaman D, Pan H, El-Assal O, Rajesh M, Mukhopadhyay P, Hong F, Harvey-White J, Jafri A, Hasko G, Huffman JW, Gao B, Kunos G, Pacher P. Cannabinoid-2 receptor mediates protection against hepatic ischemia/reperfusion injury. FASEB J 2007;21:1788-1800. [PubMed: 17327359]

4. Batkai S, Rajesh M, Mukhopadhyay P, Hasko G, Liaudet L, Cravatt BF, Csiszar A, Ungvari Z, Pacher P. Decreased age-related cardiac dysfunction, myocardial nitrative stress, inflammatory gene expression, and apoptosis in mice lacking fatty acid amide hydrolase. Am J Physiol Heart Circ Physiol 2007;293:H909-918. [PubMed: 17434980]

5. Begg M, Pacher P, Batkai S, Osei-Hyiaman D, Offertaler L, Mo FM, Liu J, Kunos G. Evidence for novel cannabinoid receptors. Pharmacol Ther 2005;106:133-145. [PubMed: 15866316]

6. Di Filippo C, Rossi F, Rossi S, D'Amico M. Cannabinoid CB2 receptor activation reduces mouse myocardial ischemia-reperfusion injury: involvement of cytokine/chemokines and PMN. J Leukoc Biol 2004;75:453-459. [PubMed: 14657208]

7. Di Marzo V, Bifulco M, De Petrocellis L. The endocannabinoid system and its therapeutic exploitation. Nat Rev Drug Discov 2004;3:771-784. [PubMed: 15340387]

8. Guindon J, Hohmann AG. Cannabinoid $\mathrm{CB}(2)$ receptors: a therapeutic target for the treatment of inflammatory and neuropathic pain. Br J Pharmacol. 2008in press

9. Klein TW. Cannabinoid-based drugs as anti-inflammatory therapeutics. Nature Rev Immunol 2005;5:400-411. [PubMed: 15864274]

10. Klein TW, Newton C, Larsen K, Lu L, Perkins I, Nong L, Friedman H. The cannabinoid system and immune modulation. J Leukoc Biol 2003;74:486-496. [PubMed: 12960289]

11. Lamontagne D, Lepicier P, Lagneux C, Bouchard JF. The endogenous cardiac cannabinoid system: a new protective mechanism against myocardial ischemia. Arch Mal Coeur Vaiss 2006;99:242-246. [PubMed: 16618028]

12. Lotersztajn S, Teixeira-Clerc F, Julien B, Deveaux V, Ichigotani Y, Manin S, Tran-Van-Nhieu J, Karsak M, Zimmer A, Mallat A. CB2 receptors as new therapeutic targets for liver diseases. Br J Pharmacol. 2008in press

13. Mechoulam R, Fride E, Di Marzo V. Endocannabinoids. Eur J Pharmacol 1998;359:1-18. [PubMed: 9831287]

14. Miller AM, Stella N. CB(2) receptor-mediated migration of immune cells: it can go either way. Br J Pharmacol. 2008in press

15. Montecucco F, Burger F, Mach F, Steffens S. The CB2 cannabinoid receptor agonist JWH-015 modulates human monocyte migration through defined intracellular signaling pathways. Am J Physiol Heart Circ Physiol. Jan;2008 10.1152/ajpheart.01328.2007

16. Mukhopadhyay P, Batkai S, Rajesh M, Czifra N, Harvey-White J, Hasko G, Zsengeller Z, Gerard NP, Liaudet L, Kunos G, Pacher P. Pharmacological inhibition of CB1 cannabinoid receptor protects against doxorubicin-induced cardiotoxicity. J Am Coll Cardiol 2007;50:528-536. [PubMed: 17678736]

17. Pacher P, Batkai S, Kunos G. The endocannabinoid system as an emerging target of pharmacotherapy. Pharmacol Rev 2006;58:389-462. [PubMed: 16968947]

18. Pacher P, Hasko G. Endocannabinoids and cannabinoid receptors in ischaemia-reperfusion injury and preconditioning. Br J Pharmacol. 2008in press

19. Pertwee RG. Cannabinoids and multiple sclerosis. Mol Neurobiol 2007;36:45-59. [PubMed: 17952649]

20. Pertwee RG. The therapeutic potential of drugs that target cannabinoid receptors or modulate the tissue levels or actions of endocannabinoids. AAPS J 2005;7:E625-654. [PubMed: 16353941] 
21. Rajesh M, Mukhopadhyay P, Batkai S, Hasko G, Liaudet L, Huffman JW, Csiszar A, Ungvari Z, Mackie K, Chatterjee S, Pacher P. CB2-receptor stimulation attenuates TNF-alpha-induced human endothelial cell activation, transendothelial migration of monocytes, and monocyte-endothelial adhesion. Am J Physiol Heart Circ Physiol 2007;293:H2210-2218. [PubMed: 17660390]

22. Rajesh M, Mukhopadhyay P, Hasko G, Huffman JW, Mackie K, Pacher P. CB2 cannabinoid receptor agonists attenuate TNFalpha-induced human vascular smooth muscle cell proliferation and migration. Br J Pharmacol. 2008in press

23. Rajesh M, Pan H, Mukhopadhyay P, Batkai S, Osei-Hyiaman D, Hasko G, Liaudet L, Gao B, Pacher P. Pivotal Advance: Cannabinoid-2 receptor agonist HU-308 protects against hepatic ischemia/ reperfusion injury by attenuating oxidative stress, inflammatory response, and apoptosis. J Leukoc Biol 2007;82(6):1382-9. [PubMed: 17652447]

24. Steffens S, Mach F. Cannabinoid receptors in atherosclerosis. Curr Opin Lipidol 2006;17:519-526. [PubMed: 16960500]

25. Steffens S, Veillard NR, Arnaud C, Pelli G, Burger F, Staub C, Karsak M, Zimmer A, Frossard JL, Mach F. Low dose oral cannabinoid therapy reduces progression of atherosclerosis in mice. Nature 2005;434:782-786. [PubMed: 15815632]

26. Van Sickle MD, Duncan M, Kingsley PJ, Mouihate A, Urbani P, Mackie K, Stella N, Makriyannis A, Piomelli D, Davison JS, Marnett LJ, Di Marzo V, Pittman QJ, Patel KD, Sharkey KA. Identification and functional characterization of brainstem cannabinoid CB2 receptors. Science 2005;310:329-332. [PubMed: 16224028]

27. Wright KL, Duncan M, Sharkey KA. Cannabinoid CB(2) receptors in the gastrointestinal tract: a regulatory system in states of inflammation. Br J Pharmacol. 2008in press

28. Zhang M, Martin BR, Adler MW, Razdan RK, Jallo JI, Tuma RF. Cannabinoid CB(2) receptor activation decreases cerebral infarction in a mouse focal ischemia/reperfusion model. J Cereb Blood Flow Metab 2007;27:1387-1396. [PubMed: 17245417] 